\title{
THE EFFECT OF BILIMBI (BELIMBING WULUH) EXTRACT (Averrhoa bilimbi L) AGAINST DENTAL REMINERALISATION AND ENAMEL MICROSTRUCTURE (IN VITRO RESEARCH)
}

\author{
PENGARUH EKSTRAK BUAH BELIMBING WULUH (Averrhoa bilimbi L) \\ TERHADAP REMINERALISASI GIGI DAN MIKROSTRUKTUR EMAIL \\ (PENELITIAN IN VITRO)
}

\author{
Trimurni Abidin* Marline Nainggolan** Susi* \\ *Conservative Dentistry \& Endodontic \\ ** Pharmaceutical Department \\ Faculty of Dentistry, Universitas Sumatera Utara \\ Jln. Alumni No.2 Kampus USU Medan 20155
}

\begin{abstract}
Teeth physiologically undergo demineralization and remineralisation processes. One way to reduce demineralization can be done with the use of CPP-ACP (Casein Phosphopeptide-Amorphous Calcium Phosphate), which has high calcium bioavailability. The use of natural materials products in the field of dentistry is currently growing, one of which is bilimbi/ starfruit (belimbingwuluh) that is rich in minerals and has many benefits. This study aims to analyze the effect of extract of bilimbi in tooth enamel remineralisation which is tested by using SEM and EDX equipments so that the difference of enamel surface microstructure and the amount of calcium and phosphorus content of tooth enamel surface can be identified. A total of eight hidden molar teeth were extracted, cut into four parts and divided into four groups, namely group I: the teeth applied with the wuluh bilimbi gel, group II: the teeth applied with CPP-ACP gel, group III: the teeth applied with the combination gel of starfruit extract and CPP-ACP gel, group IV: without any application. The result of this study was assessed qualitatively and it was noticeable that the treatment group combination of CPP-ACP gel and starfruit gel had the smoothest enamel surface microstructure. Quantitatively, there were significant difference is the three treatment groups $(\mathrm{p} \leq 0.05)$. The conclusion of this research is the effect of the application of wuluh bilimbi extract gel, CPP-ACP gel and gel combination of starfruit with CPP-ACP gel towards the remineralisation and microstructure of tooth enamel surface.
\end{abstract}

Keywords: CPP-ACP gel, Remineralisation, SEM and EDX, Wuluh bilimbi extract gel

\begin{abstract}
Abstrak
Gigi secara fisiologis mengalami proses demineralisasi dan remineralisasi. Salah satu cara untuk mengurangi demineralisasi dapat dilakukan dengan penggunaan bahan CPP-ACP (Casein Phosphopeptide-Amorphous Calcium Phosphate), yang memiliki bioavailabilitas kalsium tinggi. Penggunaan produk-produk bahan alam dibidang kedokteran gigi saat ini semakin berkembang, salah satu diantaranya buah belimbing wuluh yang kaya dengan mineral dan mempunyai banyak khasiat. Penelitian ini bertujuan menganalisa pengaruh pemberian ekstrak buah belimbing wuluh dalam remineralisasi enamel gigi yang diuji dengan menggunakan alat SEM dan EDX sehingga dapat diketahui perbedaan mikrostruktur permukaan enamel dan jumlah kandungan unsur kalsium dan fosfor permukaan enamel gigi. Sebanyak delapan gigi molar terpendam yang sudah di ekstraksi, dipotong menjadi empat bagian dan dibagi menjadi empat kelompok, yaitu kelompok I: gigi diaplikasi dengan gel buah belimbing wuluh, kelompok II: gigi diaplikasi dengan gel CPP-ACP, kelompok III: gigi diaplikasi dengan kombinasi gel ekstrak buah belimbing wuluh dan gel CPPACP, dan kelompok IV: tanpa dilakukan aplikasi apapun. Hasil penelitian ini dinilai secara kualitatif dan terlihat bahwa kelompok perlakuan kombinasi gel CPP-ACP dan gel buah belimbing memiliki mikrostruktur permukaan email paling halus. Secara kuantitatif menunjukkan terdapat perbedaan signifikan pada ketiga kelompok perlakuan $(p \leq 0,05)$. Kesimpulan penelitian ini adalah adanya pengaruh pemberian gel ekstak buah belimbing wuluh, gel CPP-ACP dan
\end{abstract}


kombinasi gel ekstak buah belimbing wuluh dengan gel CPP-ACP terhadap remineralisasi dan mikrostruktur permukaan enamel gigi.

Kata Kunci: Gel ekstak buah belimbing wuluh, Gel CPP-ACP, Remineralisasi, SEM dan EDX

\section{INTRODUCTION}

Email and dentin in the human oral cavity always experience a demineralisation and remineralisation cycle. The acid localized by plaque after a cariogenic attack causes a low $\mathrm{pH}$ of the tooth surface, then diffuses into the tooth causing the dissolution of calcium and phosphate from the enamel. At this time, the $\mathrm{pH}$ of the oral cavity may fall below the critical $\mathrm{pH}$ of the email which is 5.5 which will lead to the release of minerals and the weakening of the mechanical properties of the enamel and will cause damage to the teeth enamel structure. ${ }^{1}$

Demineralisation can be overcome by using fluoride, although excessive doses will cause fluorosis, thus many researchers look for the alternatives to anticariogenic agents that do not cause fluorosis. ${ }^{2}$ The first reverse mineralisation material disclosed in 1998 was CPP-ACP (Casein Phosphopeptide-Amorphous Calcium Phosphate) or better known as the casein phosphopeptide complex and amorphous calcium phosphate. A study have proven that CPP-ACP is a substance that has anticariogenic activity in animals and humans in in situ experiments. ${ }^{3}$

Therefore, CPP-ACP was chosen as one of the ingredients in the field of dentistry derived from casein derivatives and is a good material to fight caries disease. ${ }^{3}$ CPP-ACP has deficiencies which have low solubility in an acidic atmosphere; this causes the decreased ability of CPP-ACP to hold calcium and phosphate ions in acidic environment. ${ }^{4}$

The National Program Policy for the Development of Natural Resources by making Indonesia as the number one manufacturer in the world in naturalbased medicine industry (World First Class Herbal Medicine Country) in 2020, one of the medicinal plants that has been used since the first is wuluh star fruit (bilimbi), this plant gets extremely huge attention recently as the result of the evidence of scientific studies stating that the bilimbi wuluh is rich with minerals and has numerous advantages. Particularly in the field of dentistry, the minerals contained in the star fruit include calcium and phosphorus which are good for remineralising the tooth enamel. ${ }^{5}$ Wuluh bilimbi also contains lactic acid which is known to have the ability to bind calcium ions and provides buffer in acidic environment so that remineralisation process can occur. ${ }^{7}$ This study aims to compare the effects of CPP-ACP gel, wuluh bilimbi extract (Averrhoa bilimbi L) and combination of the bilimbi extract gel (Averrhoabimlimbi $L$ ) added with CPP$\mathrm{ACP}^{6}$

\section{MATERIALS AND METHODS}

Wuluh bilimbi (star fruit) as much as $5 \mathrm{~kg}$ is wetsorted, then thinly sliced inserted into the drying cupboard with a temperature of $40-50^{\circ} \mathrm{C}$. The dried fruit is then crushed (simplicia) and put into a closed container and then added 75 parts of ethanol solvent, sealed, left for 5 days while frequently stirred, scraped, squeezed, the pulp is washed with ethanol solvent until 100 parts of the extractor are obtained. It is left for 2 days, filtered and then concentrated with a rotary evaporator at the temperature of $40-60^{\circ} \mathrm{C}$. The extract of wuluh starfruit that has been concentrated is weighed with concentration of $0.25 \%$ from base HPMC and crushed until it becomes homogeneous, then put into a closed container (Figure 1). 


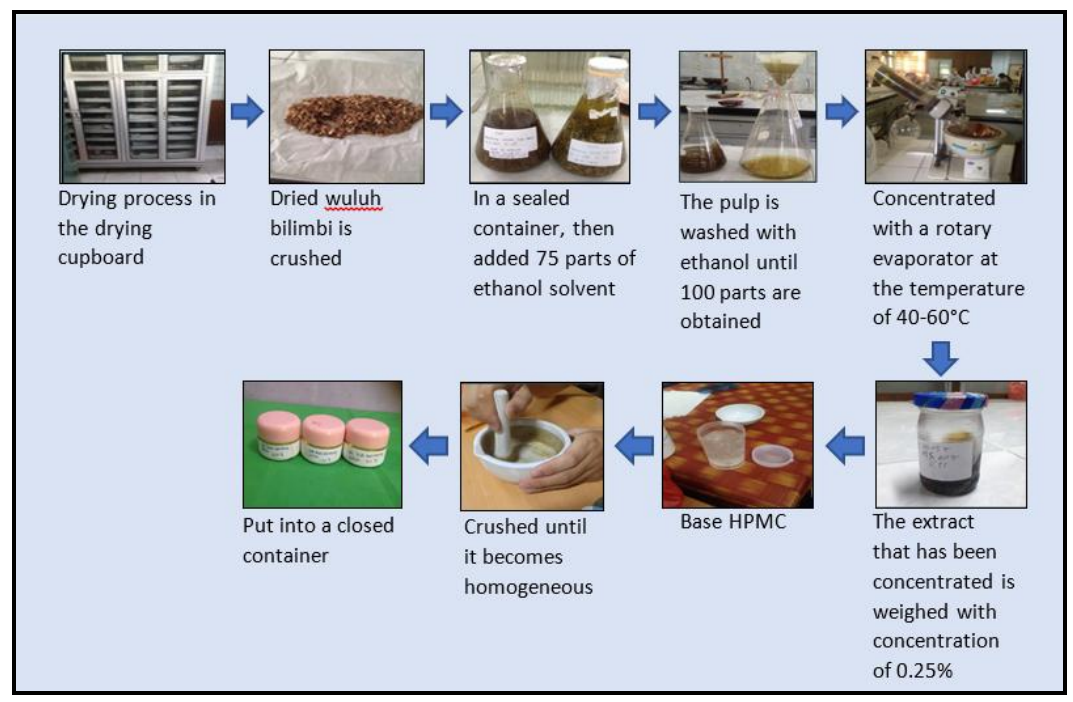

Figure 1. The Process of Producing Wuluh Bilimbi Gel

The study sample used eight newly extracted molar teeth. Each of the dental crowns is divided into four parts in the mesio-distal and bucco-lingual directions which will be divided into four groups. The tooth sample is then implanted into a paralon pipe that has been filled with acrylic resin so that the upper part of buccal or lingual area of approximately 4 $\mathrm{x} 4 \mathrm{~mm}$ is visible. Each group was soaked in demineralisation solution for 4 days, then group I: Teeth were applied with $0.25 \%$ bilimbi extract gel, Group II: Teeth were applied with CPP-ACP gel, Group III: Teeth were applied with a combination of wuluh bi- limbi extract gel $0.25 \%$ and CPP-ACP gel with a ratio of 1: 1 then stirred, and Group IV: Without application, only incubated in artificial saliva for 7 days.

Apply groups I, II, and III as much as 1 time for 4 minutes, after being left for 10 minutes, and incubated in artificial saliva for 7 days. On the 8th day, sample testing was done using SEM and EDX equipments. Sample testing with SEM aims to determine the microstructure of the enamel surface, while EDX examination aims to determine the $\%$ ratio of the weight of $\mathrm{Ca}$ and $\mathrm{P}$ elements in each group.

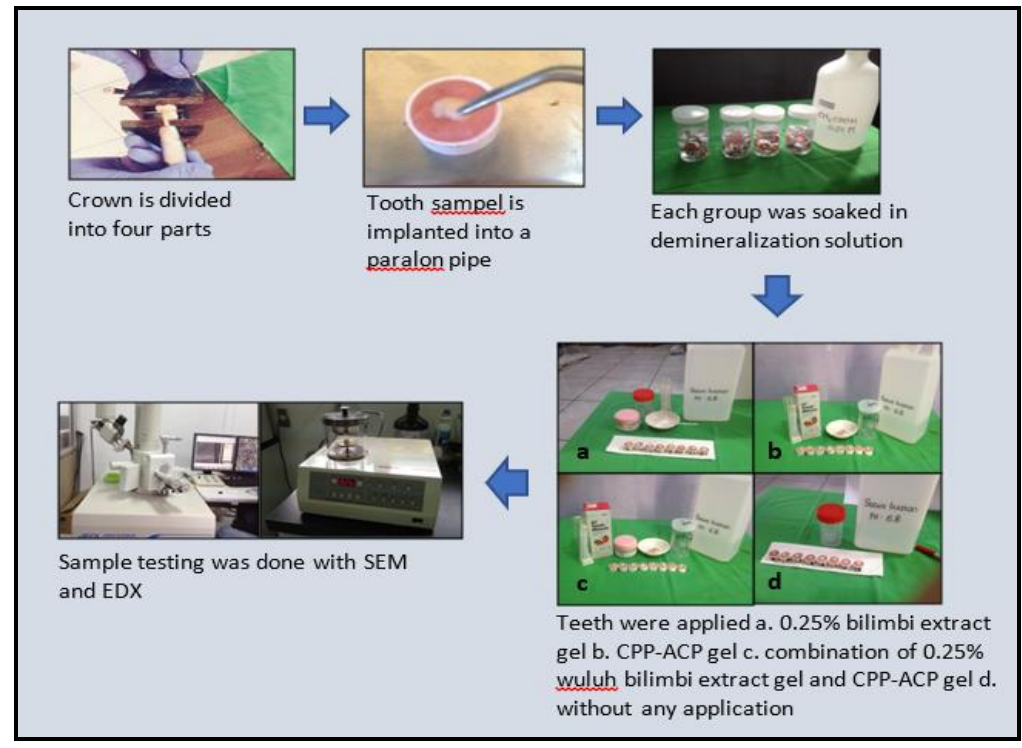

Figure 2. The procedure of the treatment on the study 
Data from SEM test result was statistically tested using Mann - Whitney analysis test to see the significant difference between each treatment group on the microstructure of enamel surface, while data from EDX test result was statistically tested using statistical test of one-way variance analysis (ANOVA) to know the difference of enamel remineralisation in each group. Bonferroni tests were then conducted to determine the significant difference between the calcium $(\mathrm{Ca})$ and phosphorus $(\mathrm{P})$ elements on the enamel surface among the treatment groups.

\section{RESULT}
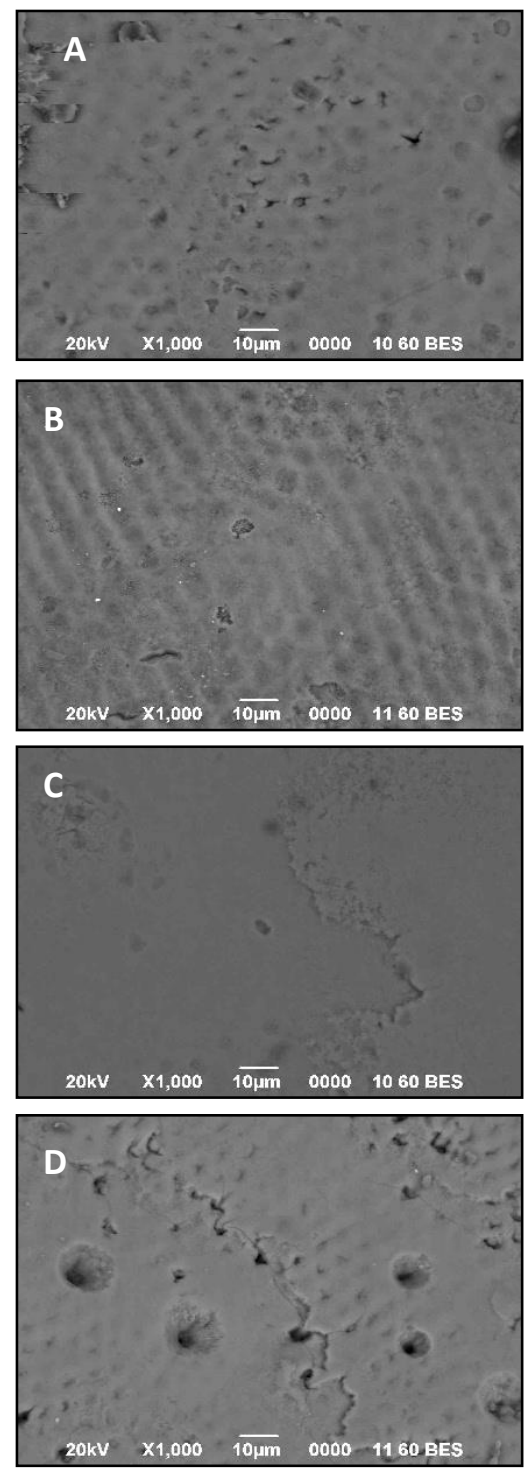

Figure 3. SEM examination result displays the microstructure of enamel structure on A. The enamel group after the application with wuluh bilimbi extract gel, B. CPP- ACP gel, C. The combination of wuluh bilimbi extract gel and CPP-ACP gel and on D. Without any application

The result of SEM testing (Figure 3A), shows the surface of microstructure of email to be more flat, but some parts of the email rod look with darker colour in the middle, which states that the damage remains, however, the difference with the surrounding colour is not too large, therefore indicates that the damage to the enamel layer is not too deep and the number of pores is smaller when compared to (Fig. 3D). Figure 3B, the surface of the microstructure of the email with a smaller number of pores which indicates less damage after application with CPP-ACP gel is seen. Figure. 3C, showing the microstructure of enamel surfaces with smaller pores and micro structural surface of the enamel became smoother, resembling the normal surface of the enamel. Figure. $3 \mathrm{D}$, visible on the surface of the enamel microstructure with a considerable number of pores and larger size than all previously treated images, this indicates the presence of email damage and the middle of the email rod looks dark, where the occurrence of crystal damage the hydroxyapatite which composes the email layer, and to see each difference in the surface of the enamel microstructure in each group, MannWhitney analysis test is conducted (Table. 1).

Table 1. Mann-Whitney Test Result

\begin{tabular}{ccccc}
\hline Group & I & II & III & IV \\
\hline I & - & 0.288 & $0.001^{*}$ & $0.001^{*}$ \\
II & 0.288 & - & $0.012^{*}$ & $0.007^{*}$ \\
III & $0.001^{*}$ & $0.012^{*}$ & - & $0.001^{*}$ \\
IV & $0.001^{*}$ & $0.007^{*}$ & $0.001^{*}$ & - \\
\hline
\end{tabular}

Description: *significant if $\alpha \leq 0,05$

Table 1 shows that there is significant difference in enamel surface microstructure among all treatment groups, except between group I and group II. The results of observations with EDX obtained data content of $\mathrm{Ca}$ and $\mathrm{P}$ elements in \% weight and then ANOVA test is conducted. The result of test of $\mathrm{Ca}$ element content showed that $\mathrm{p}=0.021(\mathrm{p}<0.05)$ which means that there was significant difference of amount of $\mathrm{Ca}$ element among all treatment groups, while $\mathrm{P}$ element showed $\mathrm{p}=0.110(\mathrm{p}<0.05)$ a signi- 
ficant difference in the amount of $\mathrm{P}$ content in all treatment groups (Table 2).

Table 2. Descriptive Data that Displays the Mean Value and Standard Deviation from AnovaTest on the Calcium (Ca) and Phosphorus (P) Elements Content Test of Enamel Surface in Each Group

\begin{tabular}{|c|c|c|c|c|c|c|}
\hline \multirow{2}{*}{ Group } & \multicolumn{3}{|c|}{$\begin{array}{c}\text { C }_{\mathrm{A}} \text { ELEMENT ( } \% \\
\text { WEIGHT) }\end{array}$} & \multicolumn{3}{|c|}{$\begin{array}{l}\text { P ELEMENT (\% } \\
\text { WEIGHT) }\end{array}$} \\
\hline & $\mathrm{N}$ & $\begin{array}{l}\mathrm{X} \pm \\
\mathrm{SD}\end{array}$ & $\mathrm{P}$ & $\mathrm{N}$ & $\begin{array}{l}\mathrm{X} \pm \\
\mathrm{SD}\end{array}$ & $\mathrm{P}$ \\
\hline I & 8 & $\begin{array}{c}37.18 \\
\pm 7.60\end{array}$ & & 8 & $\begin{array}{r}16.56 \\
\pm 1.97\end{array}$ & \\
\hline II & 8 & $\begin{array}{r}38.92 \\
\pm 5.49\end{array}$ & & 8 & $\begin{array}{r}16.70 \\
\pm 1.96\end{array}$ & \\
\hline III & 8 & $\begin{array}{r}43.68 \\
\pm 3.49\end{array}$ & $0.021 *$ & 8 & $\begin{array}{r}17.87 \\
\pm 1.21\end{array}$ & 0.110 \\
\hline IV & 8 & $\begin{array}{c}31.49 \\
\pm \\
10.59\end{array}$ & & 8 & $\begin{array}{r}14.96 \\
\pm 3.39\end{array}$ & \\
\hline
\end{tabular}

Description: $* \mathrm{p}<0.05=$ significant difference

I : Enamel group that is applied with wuluh bilimbi extract gel

II : Enamel group that is applied with CPP-ACP gel

III :Enamel group that is applied with the combination of wuluh bilimbi extract gel and CPP- APP gel

IV : Enamel group without application

Viewing the difference in the content of $\mathrm{Ca}$ and $\mathrm{P}$ elements between each group, it can be known with certainty by doing a post hoc Bonferroni test. The result of the Bonferroni post hoc test showed that the $\mathrm{Ca}$ elements in groups III and IV had significant content differences with $p=0.002(p<0.05)$, while the $\mathrm{P}$ elements in groups III and IV had significant content differences with $p=0.016^{*}(p<0.05)$.

\section{DISCUSSION}

Testing using SEM (Scanning Electron Microscope) and EDX (Energy Dispersive X-Ray) test equipment is considered as a simple and reliable method to determine information directly on changes in mineral content in enamel. The addition or loss of minerals as a process of remineralisation and demineralisation can be measured with EDX. In this study to measure surface remineralisation of enamel, following the method undertaken by Bansode et al., 2014 that is by using the surface of intact email without polishing so as to more accurately reflect the demineralisation cycle in the oral environment. ${ }^{8}$ The results of the test obtained is a description of surface enamel microstructure with SEM test tool and the value and amount of minerals contained in the email with EDX text equipment.

The test results with SEM test equipment, the surface of the enamel microstructure in the image seems to be more flat, but some parts indicate the presence of email rod with darker colour in the middle part, which states that the damage remains, but the difference with the surrounding colour is not too large, thus indicating that the enamel layer damage is not very deep and the number of smaller pores (Figure A). The results of the test with EDX test in this group also show significant increases in $\mathrm{Ca}$ content (Table 2) and $\mathrm{P}$ content higher than the enamel surface group without application. Although the $\mathrm{pH}$ of wuluh bilimbi is 4.7 extract gel of wuluh bilimbi known to have high calcium and phosphate content, this mineral is very important needed in repair of hydroxyapatite structure which can trigger remineralisation in teeth.

Remineralisation occurring in this group is possible because Ion $\mathrm{H}+$ from the bilimbi extract gel joins the $\mathrm{HPO}_{4}{ }^{2+}$ from artificial saliva will be converted to $\mathrm{HPO}_{4}^{-}$and $\mathrm{H}_{2} \mathrm{PO}_{4}^{-}$, so as to maintain the degree of salivary acidity. After salivary $\mathrm{pH}$ becomes normal again, $\mathrm{H}_{2} \mathrm{PO}_{4}{ }^{2-}$ in saliva binds to $\mathrm{Ca}^{2+}$ from extract gel of bilimbi to become $\mathrm{CaHPO}_{4}{ }^{0}$ which will diffuse into the enamel. This is in accordance with a study by Kartini in 2015 on the effects of processed cheese on remineralisation in premolar teeth which shows the result that processed cheese, despite having a low $\mathrm{pH}$, is effective to increase remineralisation in enamel lesions ${ }^{9}$ and also supported by Marilia et al., (2011), shows that artificial saliva may increase remineralisation of enamel surface after demineralisation happens, causing calcium and phosphate in an alkaline or neutral environment to benefit for the occurrence of remineralisation, and calcium and phosphate in artificial saliva also act to substitute the minerals lost from tooth enamel. $^{10}$

This research is an in vitro research, the solution component in this case is artificial saliva, newly given to sample after giving the extract gel of wuluh bilimbi, if research is conducted in in vivo, saliva factor is produced directly by human subject, hence the $\mathrm{pH}$ of the extract gel of wuluh bilimbi which tends to be acid will help increasing the $\mathrm{pH}$ of the oral cavity through stimulation or increased saliva flow rate in the oral cavity. This is also supported by an in vivo study by Anatasia et al. (2011), who 
examined that consuming yoghurt with a $\mathrm{pH}$ of 5.0 may increase salivary flow rate by $\mathrm{pH} 7.0$ in minutes so that it would not affect remineralisation ability, since it can help improving the $\mathrm{pH}$ of the oral cavity. ${ }^{11}$

The CPP-ACP paste used in this study are that which is already available in the form of products with the trademarks that have been claimed to fight demineralisation, increase saliva flow, increase fluorine absorption, restore minerals, strengthen tooth enamel, neutralize plaque and bacterial acids and alleviate tooth surface sensitivity. In accordance with Turssi et al's research, 2011, previously, which investigated the effects of various remineralisation ingredients on acid-exposed enamel, it was found that CPP-ACP gel results could reduce the progression of erosion lesions in enamel. The CPP-ACP gel provides a certain amount of calcium and phosphorus that can prevent demineralisation and increase the remineralisation of acid-exposed enamel. ${ }^{12}$

Some studies have reported that the CPP-ACP gel can penetrate further into tooth enamel to replace calcium and phosphate ions lost due to demineralisation. Oshiro et $\mathrm{al}^{13}$ conducted a study on the effects of CPP-ACP paste on tooth remineralisation using SEM test equipment and showed that CPP-ACP paste effectively prevents demineralisation of enamel and dentine. The SEM image of enamel and dentin showed that the CPP-ACP-pasted teeth experienced fewer morphological changes after immersion in acidic solutions compared to the group without CPP-ACP gel application (Tooth Mousse). ${ }^{13}$

This study showed SEM test results, seen in (Fig. B) the number of pores are smaller than the tooth enamel surface without application and enamel surfaces applied with the extract of wuluh bilimbi, indicating the decrease of damage after the application with gel CPP-ACP, whereas EDX test result showed a significant increase of the remineralisation of tooth enamel surface which showed that $\mathrm{Ca}$ content and $\mathrm{P}$ content were higher than the enamel surface group without application and enamel surface group applied with wuluh bilimbi extract gel (Table 2). This may be because CPP is completely binding calcium and phosphate in the form of ACP and this compound can directly enter the surface of the enamel resulting in remineralisation. Meanwhile, the extract gel of the star fruit still has to stabilize the calcium phosphate in saliva solution. Therefore, the extract gel of bilimbi may be able to react completely if there is a solution component such as saliva at the time of its application. Meanwhile, in this study which is an in vitro study, a new artificial salivary solution component was then administered to the sample after the extract gel of the star fruit gel was applied to the enamel.

This study, showing the SEM results in the group (Figure $3 \mathrm{C}$ ), appears to be a smaller number of pores and the micro structural surface of the enamel becomes smoother, resembling the normal surface of enamel. The results of the test with the EDX test equipment showed an increase in enamel surface remineralisation significantly that the $\mathrm{Ca}$ and $\mathrm{P}$ content of this group, when compared with all other groups, the result is higher in remineralising the enamel surface (Table 1). This is possible because the $\mathrm{PO}_{4}{ }^{3-}$ from ACP binds to the $\mathrm{H}^{+}$ions from the extract gel of the star fruit to normalize the $\mathrm{pH}$ of the solution, then the other $\mathrm{PO}_{4}{ }^{3-}$ binds to the calcium to diffuse into the tooth enamel. The increase of $\mathrm{H}^{+}$ions in solution will be balanced out by the decrease of $\mathrm{OH}^{-}$ and $\mathrm{PO}_{4}{ }^{3-}$ ions. If the CPP-ACP combination with the extract gel of star fruit is applied it will release phosphate which becomes one of the saliva buffers. $\mathrm{H}^{+}$ions will join the $\mathrm{PO}_{4}{ }^{3-}$ from $\mathrm{ACP}$ and converted to $\mathrm{HPO}_{4}^{-}$and $\mathrm{H}_{2} \mathrm{PO}_{4}^{-}$, can be used to maintain salivary acidity degree. After the salivary $\mathrm{pH}$ becomes normal again, the $\mathrm{H}_{2} \mathrm{PO}_{4}{ }^{2-}$ in saliva binds to $\mathrm{Ca}^{2+}$ from a combination of star fruit extract of wuluh and CPP-ACP gel to $\mathrm{CaHPO}_{4}{ }^{0}$ which will diffuse into enamel. This is in accordance with a study by Fitri et al., 2014, where enamel surfaces applied with a combination of CPP-ACP and chitosan gel, resulted in better remineralisation on tooth enamel surfaces when compared to enamel after CPP-ACP gel is applied. This is due to the interaction between two remineralisation materials that complements each other's deficiencies of each of these materials. ${ }^{14}$

Based on the result of research on the effect of extract gel of wuluh bilimbi (Averrhoa bilimbi L) to remineralisation of tooth and enamel microstructure with SEM and EDX test, it can be concluded that the wuluh bilimbi (Averrhoa bilimbi L) extract gel, CPP-ACP gel and combination the wuluh bilimbi (Averrhoa bilimbi L) extract gel with CPP-ACP gel can significantly affect the surface remineralisation of tooth enamel. 


\section{REFERENCES}

1. Kalra DD, Kalra RD, Kini PV, Prabhu A. Non fluoride remineralization: an evidence-based review of contemporary technologies. J Dental and Allied Science 2014; 3(1): 24-33.

2. Alvarez JA, Rezende KMPC, Marocho SMS, Alves FBT, Celiberti P, Ciamponi AL. Dental fluorosis: exposure, prevention and management. J Clin Exp Dent 2009; 1(1): 14-8.

3. Moezizadeh M, Moayedi S., 2009. Anticariogenic effect of amorphous calcium phosphate by casein phosphopeptid: a review article. Res J BiolSci; 4(1): 132-6.

4. Hong L, Hottel T, Godoy FG, Gan L. Methods and compositions of chitosan-amorphous calcium phosphate based multifunctional biomaterial. <http: //utrf.technologypublisher.com/technology 13361> (15 Juni 2014)

5. Keputusan Menteri Kesehatan Republik Indonesia. Kebijakan obat tradisional nasional (KONTRANAS). Jakarta: Kementerian Kesehatan Republik Indonesia, 2007. Nomor 381/MENKES/SK/III/ 2007.

6. Zakaria ZA, Zaiton H, Henie EFP, Mat Jais AM, Engku Zainuddin ENH. In vitro Antibacterial Activity of Averrhoabilimbi L. Leaf and Fruits Extracts. Int. J. Trop. Med 2007; 2(3): 96-100.

7. Yamazaki H, Litman A, Margolis HC. Effect of fluoride on artificial caries lesion progression and repair in human enamel: regulation of mineral deposition and dissolution under in vivo-like conditions. Arch Oral Biol 2007; 52(2): 110-20.

8. Bansode, PV, Deore R, Pathak S., 2014. Evaluation of the effect of casein phosphopeptide- amorphous calcium phosphate on tooth enamel demineralized by a carbonated soft drink using micro hardness testing method: an in vitro study. Int J Sci Study 2014; 2(8): 24-8.
9. Kartini. Pengaruh pemendaman gigi dalam keju terhadap peningkatan kekerasan mikro permukaan email gigi manusia (in vitro). Skripsi. Fakultas Kedokteran Gigi Universitas Hasanudin Makassar, 2015:1-77.

10. Buzalaf MA, Hannas AR, Kato MT. Saliva and dental erosion. J Appl Oral Sci 2012; 20(5): 493502.

11. Siswosubroto AE, Pangemanan DHC, Leman MA. Gambaran komsumsi yoghurt terhadap waktu peningkatan $\mathrm{pH}$ saliva. PHARMACON J Ilmiah Farmasi 2015; 4(4): 46-51.

12. Turssi CP, Maeda FA, Messias DC, Neto FC, Serra MC, Galafassi D. Effect of potential remineralizing agents on acid softened enamel. Am J Dent 2011; 24 (3): 165-8.

13. Oshiro M, Yamaguchi K, Takamizawa T, Inage H, Watanabe T, Irokawa A, et al. Effect of CPP-ACP paste on tooth remineralization: an FE-SEM study. Int J Oral Science 2007; 49(2): 115-20

14. Batubara FY, Abidin T, Agusnar H 2014. Pengaruh Penambahan Kitosan Nano partikel pada Casein Phosphopeptid-Amorphous Calcium Phosphate (CPP-ACP) terhadap remineralisasi Gigi (In Vitro). Dentika Dent J 2014; 18(1): 16-20. 